\title{
PENDIDIKAN DIMENSI TASAWUF MEMBANGUN MORAL ANAK DIDIK
}

\author{
Hadarah Rajab ${ }^{1}$ \\ ${ }^{1}$ IAIN Syaikh Abdurrahman Siddik Bangka Belitung
}

\begin{tabular}{l}
\hline \hline Info Artikel : \\
\hline Diterima 5 September 2020 \\
Direvisi 9 September 2020 \\
Dipublikasikan \\
30 September 2020 \\
\end{tabular}

\section{Kata Kunci:}

Pendidikan

Tasawuf

Moral

\begin{abstract}
ABSTRAK
Manusia modern semakin terkontaminasi oleh rasa cemas dan kehilangan visi keilahian serta kehilangan dimensi transdental, sehingga mudah dihinggapi kegersangan dan kritis spiritual.Sebagai akibatnya, manusia modern sering dihinggapi penyakit setress, depresi dan alusinasi.Mereka teralusisnasi dengan dirinya sendiri, dari lingkungan sosialnya dan yang terpenting lagi seolah-olah pesan dari Tuhannya.Kesenjangan antara identitas dan peran agama di satu sisi dan kenyataan masyarakat beragama di sisi lain sebagai dampak modernisme, menunjukkan lemahnya peran agama ditengah-tengah masyarakat. Karena agama yang dipahami oleh masyarakat tampaknya masih sebatas pemahaman dan pengalaman agama secara formalistik.Pemahaman dan pengamalan agama pada masyarakat belum sampai menyentuh pada tingkat penghayatan batiniyah dari hakikat agama.Pemahaman dan pengamalan seperti itu tidak banyak berpengaruh terhadap pembinaan moral.Apalagi jikalau agama hanya dijadikan sebagai simbol pengakuan belaka, tanpa pemahaman dan pengamalan.
\end{abstract}

Bagi setiap insan manusia, baik secara pribadi maupun secara unversal, tentu saja menghendaki sebuah hasil pencapaian hidup yang maksimal agar biasa eksis. Untuk pencapaian level yang paripurna tersebut, membutuhkan upaya secara berkelanjutan dan konsisten pada jalan spiritual sembari menekenuni latihan dan olahan batin, dengan upaya maksimal itulah meberi jalan pintas bagi seseorang mencaoai suatu kecerdasan maksimal yang disebut intlek (intelektus). Media intelek inilah kemudian berfungsi sebagai untuk mengendalikan langkah hidup dan pencapaian yang layak sampai pada visi keabadian, sekaligus menapis sikap dan praktek pragmatism, kepentingan temporal manusia.Manusia dapat menoropong sendisendi kebaikan dirinya secara spesifik demi eksistensi kebaikan universal.Manusia pada dimensi ini, telah mencapai pengetahuan substantif secara filsafati dan damai dalam keabadaian hakiki secara spiritual.Maka degan inilah terbangun sebuah landasan spiriiutal tasawuf yang sekaligus actuality.

Tasawuf dapat dihami sebagai bagian dari aspek keilmua Islam secara khusus meurpakan dimensi pembersihan jiwa ruhaniah manusia yang menjadi morot penggerak semangat dan jiwa moral yang penuh dengan sikap santun dan keperibadian sebagai 'tauladan'. Sejatinya, ilmu tasawuf pada mulanya tidak terpisahkan dengan serangkaian olahan batin yang disebut dalam ilmu tasawuf sebagai tazkiyah an-nafs, pada aspek ini menjadi jalan yang mutlak dilalui bagi setiap insan yang menjalani atau pementasan spiritualitas dirinya. Dalam perjalanan spiritual para sufi adalah pengendalian diri dari intrik-intrik dunawiah, mengindarkan diri dari segala bentuk rangsangan (godaan) materi, sebab godaan materi ini dipandangan sebagai biang dari segala penghacuran menuju keabadian; yakni 'insan suci'. Ini menggambarkan bahwa betapa detealnya perjalanan yang 
harus ditempuh selama hayat dikandung dikenal dengan mujahadah yakni perjuangan sepanjang hidup manusia. Mujahadah sebagai evisentrum terjalinnya hubungan timbal balik antara hamba dengan Tuhannya demikian sebalik, Tuhan yang dituju akan hadir dan senantiasa mengintai dirinya, menjaga sikap dan perilaku diri untuk selalu dan selamanya menjadi peribadi yang baik, teladan dan terpercaya, inilah model akhlak yang harus diinplementasikan dalam hidup keseharian manusia, menjadi terdidik dan intiqamah.

Keywords:

Education

Sufism

Moral

\begin{abstract}
Modern humans are increasingly contaminated with anxiety and lose the vision of divinity and lose the transcendental dimension, so they are easily seized with spiritual aridity and criticality. As a consequence, modern humans are often afflicted with stress, depression, and hallucinations. They are hallucinating with themselves, from their social environment, and most importantly, as if it were a message from their God.The disparity between identity and the role of religion on the one hand and the reality of religious society on the other hand, as a result of modernism, shows the weak role of religion in society. Because the religion that is understood by the community seems to be still limited to understanding and experiencing religion in a formalistic manner. The understanding and practice of religion in society have not yet reached the level of inner appreciation of the nature of religion. Such understanding and practice have little effect on moral formation. Especially if religion is only used as a symbol of recognition, without understanding and practice.
\end{abstract}

Humans, to be able to reach an existential level, of course, have to make the spiritual ascent and train their intellectual acuity. Fragmentary knowledge cannot be used to see the complete reality unless he has an intellectual vision of the whole. Whereas in every case complete knowledge about nature cannot be achieved but must be through knowledge from the center (center) because this knowledge also contains divine knowledge which can essentially be a link between the servant and his creation. Man can know himself perfectly, only if he has the help of God's knowledge because a relative existence will only be meaningful if he is tied to the Absolute, namely 'God'

Sufism is a field of Islamic studies that focuses its attention on efforts to clean up aspects of the human inner self that can revive the noble morals. So as a science since the beginning of Sufism, it cannot be separated from the tazkiyah al-Nafs (purification of the mind/soul). This effort is then theorized in the stages of self-control and certain disciplines from one stage to the next so that it reaches a spiritual level (maqam) which is referred to by the Sufis as zhuhud (testimony), form (encounter), or mortal '(self-annihilation). With a clear heart, according to a Sufistic perspective, a person is believed to be able to give up his devotions and maintain behavior because he can feel a closeness to Allah SWT.

This is an open access article distributed under the Creative Commons Attribution License, which permits unrestricted use, distribution, and reproduction in any medium, provided the original work is properly cited. (C) 2019 by author.

\section{Koresponden:}

Hadarah

Email: hadarah.rajab@iainsasbabel.ac.id 


\section{PENDAHULUAN}

Suatu kajian yang mendasar dalam hal konteks pembinaan moral anak didik dan bahkan untuk membina perilaku (moral)masyarakat, dan bangsa melalui tasawuf. Mendapa demikian, karena hakikat dari ajaran tasawuf bermuatan nilai-nilai pendidikan dan ajaran moral (akhlak.Sebagaimana Rasulullah SAW. Telah dijadikan jargon bagi kalangan ummat Islam bahwa tugas Rasulullah sebagai penyempurnah untuk akhlak manusia dari yang tidak berakhlak, kemudian menjadi berakhlak terpuji (dimuliakan).Dan juga dalam kandungan yang termuat dalam al-Quran yang menjadi sumber utama ajaran Islam, sebagaimana Fazlur Rahman menilai bahwa yang utama adalah nilai moral. ${ }^{1}$ dan itulah kenapa akhlak Rasulullah dipandang sebagai al-Qur'an. ${ }^{2}$

Dalam pandangan di atas dapat dinilai bertapa penting (urgensi0 tasawufterhadap pembentukan dan dibinanya moral bagi anak didik, secara fenomena suatu kenyataan yang dapat dilihat, nampakknya seseorang, baik individu maupun masyarakat secara luas mereka menganut agama sekalipun, tidakk menjamin mereka menjadi atau memiliki akhlak atau moralitas yang baik. Sebagaimana misalnya; bangsa Indonesia yang mayoritas adalah penganut agama (masyarakat religious), "toh" tindakan amoral masih tejadi dimana-mana, kbrutalan dan yang melanggar hak asasi manusia, tindakan korupsi,praktek kolusi, tindakan suap menyuap untuk sebuah jabatan dan pemenangan tertentu, pelacuran dan prostitusi, minum minuman keras (miras), serta over dosis dengan obat-obatan terlarang, terjadi perampokan, pembegalan dijalan-jalan, pencurian, dan tindak criminal lainnya, sederet perilaku amoral dimuat di media sosial, pertelevisian, dan berita onlie dapat didengarkan pada itulah fenomena yang mewarnai pemberitaan dimedia massa.

Demikian di lain pihak, modernisasi (modernism) atau (post-modernisme) melalui upaya memajukan ilmu pengetahuan dan tekhnologi, ternyata telah gagal memberikan kehidupan yang nyaman, terarah dan bermakna. Moedernisme justru telah membawa dampak terhadap terjadinya kerancuan dan penyimpangan nilai-nilai kemanusiaan (dehumanisasi).Manusia modern semakin terkontaminasi oleh rasa cemas dan kehilangan visi keilahian serta kehilangan dimensi transdental, sehingga mudah dihinggapi kegersangan dan kritis spiritual.Sebagai akibatnya, manusia modern sering dihinggapi penyakit setress, depresi dan alusinasi.Mereka teralusisnasi dengan dirinya sendiri, dari lingkungan sosialnya dan yang terpenting lagi seolah-olah pesan dari Tuhannya. ${ }^{3}$

Kesenjangan sebagaimana yang dikemukakan di atas, yaitu antara identitas dan peran agama di satu sisi dan kenyataan masyarakat beragama di sisi lain sebagai dampak modernisme, menunjukkan lemahnya peran agama ditengah-tengah masyarakat. Karena agama yang dipahami oleh masyarakat tampaknya masih sebatas pemahaman dan pengalaman agama secara formalistik. Pemahaman dan pengamalan agama pada masyarakat belum sampai menyentuh pada tingkat penghayatan batiniyah dari hakikat agama. ${ }^{4}$ Pemahaman dan pengamalan itu seperti itu tidak banyak berpengaruh terhadap pembinaan moral.Apalagi jikalau agama hanya dijadikan sebagai simbol pengakuan belaka, tanpa pemahaman dan pengamalan.

Sementara wacana dan issu moral bangsa diangkat karena issu ini sangat menarik dan relevan, selain inti ajaran agama (baca; tasawuf) adalah ajaran tentang moral, juga fenomena moral bangsa pada saat ini dalam kondisi yang sangat mengkhawatirkan sebagaimana disebutkan dan digambarkan di atas.

Untuk itu tema "Pendidikan Dimensi Tasawuf Membangun Moral Anak Didik" perlu diangkat dalam tulisan ini.Diharapkan tulisan ini dapat memberikan wawasan dan membuka cakrawala berpikir serta manfa'at bagi para pembaca dan penulis berikutnya.

\section{Pentingnya Agama Bagi Manusia}

Manusia terdiri dari unsur jasmani dan rohani.Kedua unsur ini menentukan postur manusia sebagai makhluk Tuhan yang paling sempurna. ${ }^{5}$ Unsur jasmani memiliki kelengkapan organik yang berfungsi sebagai mekanisme biologis.Sedangkan unsur rohani memiliki dayapikir (akal, rasio) dan

\footnotetext{
${ }^{1}$ Fazlur Rahman, Fazlur Rahman, Islam, (Bandung: Pustaka, 1404 H-1984 M), H. 36., N.D.

2 Robiah Adawiyah, “Implikasi Hermeneutika Al-Quran Fazlurrahman Dan Hasan Hanafi Terhadap Penetapan Hukum Islam,” Syariati: Jurnal Studi Al-Qur'an Dan Hukum 2, No. 01 (2016): 17-28.

${ }^{3}$ Iin Wariin Basyari, “Menanamkan Identitas Kebangsaan Melalui Pendidikan Berbasis Nilai-Nilai Budaya Lokal," Edunomic Jurnal Pendidikan Ekonomi 1, No. 2 (2013).

${ }^{4}$ B M St Aisyah, “Konflik Sosial Dalam Hubungan Antar Umat Beragama," Jurnal Dakwah Tabligh 15, No. 2 (2014): 189-208.

${ }^{5}$ (Departemen Agama, 2009; 4-5)
} 
daya rasa (dzauq, qalb) atau akal budi yang berfungsi sebagai mekanisme kejiwaan yang membedakan manusia dengan makhluk lainnya.

Agama merupakan fitrah insani yang asasi. Tanpa agama, manusia akan kehilangan kebutuhan spiritualnya. Kebutuhan manusia akan udara, air, makanan, dan sandang pangan dan papan, yang bersifat material sebagai kebutuhan jasmani, pada hakikatnya sama seperti kebutuhan manusia terhadap agama yang bersifat spiritual sebagai kebutuhan rohani. Kebutuhan yang bersifat material dapat mematikan jasmani manusia. Seperti manusia tanpa terpenuhi akan kebutuhan udara, air, makanan dan lain-lain. Demikian juga halnya kebutuhan yang bersifat spiritual juga dapat mematikan rohani manusia jika tidak terpenuhi kebutuhannya. Kenyataan membuktikan, ketika seseorang berusaha mengejar kepuasan dan kebahagiaan dengan jalan memenuhi kebutuhan material, ternyata yang diperoleh bukan yang ia cari, tetapi yang ia temukan adalah kehampaan dan kegelisahan, akhrinya ia menemukan kepuasan dan ketentraman itu dalam agama. Hal itu membuktikan bahwa agama sangat dibutuhkan oleh manusia.

Secara psikologis manusia membutuhkan ketenangan dan ketentraman batin. Ketenangan dan ketentraman batin tidak akan cukup dengan terpenuhinya kebutuhan jasmani. Berapa banyak orang yang secara material memiliki kelebihan, kemewahan dan kekayaan yang menumpuk, tetapi ternyata batinnya tidak tenang dan tidak tentram.

Uraian di atas, tidak berarti menganggap fungsi agama (Islam) hanya merespon kebutuhan rohani yang bersifat spiritual saja, tetapi agama (Islam) juga merespon kebutuhan jasmani yang bersifat material. ${ }^{6}$ Islam juga sepenuhnya merespon dalam bentuk motivasi, etos kerja, nilai etika, dan norma. Hal ini nampak jelas pada ajaran dibidang mu'amalah.Islam juga memuat kajian politik, ekonomi, sosial, budaya dan lain-lain.Sedangkan respon Islam terhadap kebutuhan spiritual terlihat jelas dalam sistim ajaran aqidah, ibadah, dan akhlak.

Secara sosiologis, manusia adalah makhluk sosial. ${ }^{7}$ Ia tidak dapat hidup seorang diri tanpa berhubungan dengan orang lain. Setiap individu akan membutuhkan individu yang lain dan demikian seterusnya sehingga terjadi saling berinteraksi antara sesame mereka. Interaksi itu terjadi dalam segala aktivitas kehidupan.Dalam aktivitas ekonomi misalnya, terjadi interaksi dalam rangka mereka memenuhi kebutuhan ekonomi. Demikian pula dalam aktivitas-aktivitas lainnya, seperti sosial, politik, budaya dan lain-lain. ${ }^{8}$ Di dalam saling berinteraksi itu sangat dimungkinkan akan terjadi disharmoni, karena mereka saling menuntut kepentingan masing-masing. Untuk mencapai kepentingan ekonomi boleh jadi terjadi pemerasan, penipuan dan lain-lain.

Masyarakat modern yang telah kehilangan visi keilahian, telah buram penglihatannya intellecusnya dalam melihat realitas hidup dan kehidupan. ${ }^{9}$.Manusia untuk dapat mencapai level yang eksistensi, tentu harus mengadakan pendakian spiritual dan melatih ketajaman intellectus. Pengetahuan fragmentaris tidak dapat digunakan untuk melihat realitas yang utuh kecuali padanya memiliki visi intellectus tentang yang utuh tadi. Bahwa dalam setiap hal pengetahuan yang utuh tentang alam tidak dapat diraih melainkan harus melalui pengetahuan dari pusat (centre), karena pengetahuan ini sekaligus mengandung pengetahuan Ilahi yang secara hakiki dapat menjadi penghubung antara hamba dengan ciptaan-Nya.Barang siapa yang dapat mengenali diri secara baik, niscaya ia dapat mengenali Tuhannya dengan lebih baik. Orang ini pada level ini, termasuk orang yang berpengetahuan luas dan mendalam, dan untuk mencapainya ia harus memastikan mengetahuai dirinya secara sempurna. Kesempurnaan itu hanya bias terjadi bila mendapatkan ilmu Ilahiyah yang disebut karuniah atau hidayah dari Allah SWT.

\section{Pendidikan Karakter}

Upaya manusia sejatinya menjadi terdidik dalam rangka mencapai perilaku baik, mengapa harus melalui pendidikan, oleh karena dengan pendidikanlah menusia dapat membentuk dan merubah peranganinya dari yang tercelah menjadi mulia. Banyak orang tua tidak megutamakan pendidikan bagi anak-anaknya secara utuh, namun mendidiknya haya sebagai tameng mendapatkan ekonomi

\footnotetext{
${ }^{6}$ Asrul Muslim, "Interaksi Sosial Dalam Masyarakat Multietnis," Jurnal Diskursus Islam 1, No. 3 (2013): 483-94.

${ }^{7}$ Ali Amran, “Peranan Agama Dalam Perubahan Sosial Masyarakat," Hikmah: Jurnal Ilmu Dakwah Dan Komunikasi Islam 2, No. 1 (2015): 23-39.

${ }^{8}$ St Aisyah, "Konflik Sosial Dalam Hubungan Antar Umat Beragama."

${ }^{9}$ Nur Hidayat, “Peran Dan Tantangan Pendidikan Agama Islam Di Era Global,” Jurnal Pendidikan Agama Islam 12, No. 1 (2015): 6174.
} 
secara cepat dan tidak memikirkan masa depan anak-anak mereka secara mendalam untuk masa tua. Nilai pendidikan otomatis menjadi barometer atas pembinaan pribadi menjadi baik.Jika tidak melalu pendidkan mustahil biasa memiliki akhlak dan moral yang baik. Mendidik bukan hanya sebatas mengharapkan dari lembaga pendidikan, namun mendidik adalah secara simultan, mulai didikan dari rumah, di luar rumah, di sekolah, di lingkangan sekitar, kesemuanya itu merupakan basis lembaga pendidikan yang secara massif, ini memberi gambaran bahwa betapa luasnya medan pendidikan, namun toh mengapa jumlah masyarakat masih tinggi yang berseliuran tanpa moral. Menjadi tugas berat bagi semua pihak, untuk menanggulangi pendakalan moral yang kian meninggi. ${ }^{10}$.Fungsi pendidikan paedagogoe dari semua pihak harus dijalankan baik secara pribadi, maupun kelompok dan lembaga.

Dalam perkembangannya, istilah pendidikan atau istilah paedagogie berarti bimbingan atau pertolongan oleh seseorang atau kelompok orang lain agar menjadi dewasa atau mencapai tingkat hidup atau penghidupan yang lebih tinggi dalam arti mental. ${ }^{11}$

Tabi'at seseorang menjadi bagian penting pada dirinya, oleh karena dengan tabi'at atau yang disebut karakter yang dapat berfungsi mengolah psikologi seseorang, dan kemudian berpengaruh pada perilakunya sebagaimana lakonnya itulah menjadi nilai yang tepat bagi dirinya dalam setiap kondisi. Telah banyak defenisi tentang karakter yang diutarakan kangan ulama dan tokoh pemikir yang tercerahkan, mulai dari kajian pespektif jaman yunani yang menyebut karakter "to mark" yakni menandai, memfokuskan, pada level aklualisasi diri (actuality) nilai-nilai kebaikan tersebut dalam bentuk tindakan atau sikap dan perilaku. Seperti; sikap santun, jujur, peduli sesama, tidak kikir, tidak tamak, senang berbagi ilmu dan tidak pelit, inilah bentuk-bentuk akhlak yang mulia.Sebaliknya, orang yang dalam kehidupan sehari-harinya hanya dapat meresahkan, mencibir, menggungjing, malasmalasan, pelit dan sebagainya.Itullah sikap yang jauh dari moral atau akhlak terpuji dan harus dibasmi. $^{12}$

Pengertian karakter menurut Pusat Bahasa Depdiknas yaitu; bawaan, hati, jiwa , kepribadian, budi pekerti, perilaku, personalitas, sifat, temperamen, watak. ${ }^{13}$ Adapun yang dimaksud berkarakter adalah; berkepribadian, berperilaku, bersifat, bertabiat, dan berwatak.Sebagian menyebutkan karakter sebagai penilaian subjektif terhadap kualitas moral dan mental, sehingga upaya mengubah atau membentuk karakter hanya berkaitan dengan stimulasi terhadap intelektual seseorang.Coon mendefenisikan karakter sebagai suatu penilaian subjektif terhadap kepribadian seseorang yang berkaitan dengan atribut kepribadiaan yang dapat diterima oleh masyarakat. Karakter berarti tabiat atau kepribadian yang merupakan keseluruhan disposisi kodrarti telah dikuasai secara stabil yang mendefinisikan seseorang individu dalam keseluruhan tata perilaku psikisnya yang merubah atau menjadikan tipikal dalam cara berpikir dan bertindak.

Kata akhlak berarti perangai, tabiat, adat istiadat.Menurut pendekatan etimologi kata akhlaq berasal dari bahsa Arab yang bentuk mufradnya adalah khuluqun. Kalimat ini mengandung segi-segi persesuaian dengan perkataan khalaqun yang berarti kejadian, serta erat hubungannya dengan khaaliq yang artinya pencipta, dan makhluq yang artinya yang diciptakan. ${ }^{14}$. Menurut ar-Raghib kosa kata alkhuluq atau al-khalaq mengandung pengertian yang sama, seperti halnya kosa kata asy-syurb dan asysyarab. Hanya saja kata al-khalaq dikhususkan untuk kondisi dan sosok yang dapat dilihat. Sedangkan al-khuluq dikhususkan untuk sifat dan karakter yang tidak dapat dilihat oleh mata. ${ }^{15}$

Menurut Mumahhamd bin Ali asy-Syarif al-Jurnaji, Akhlak adalah istilah bagi sesuatu sifat yang tertanam kuat dalam diri yang darinya keluar perbuatan-perbuatan dengan mudah, ringan, tanpa perlu berfikir dan merenung. ${ }^{16}$

Al-Ghazali menerangkan bahwa khuluq adalah suatu kondisi dalam jiwa yang suci dan dari kondisi tersebut tumbuh suatu aktifitas yang mudah dan gampang tanpa memerlukan pemikiran dan

\footnotetext{
${ }^{10}$ Hilda Ainissyifa, “Pendidikan Karakter Dalam Perspektif Pendidikan Islam,” Jurnal Pendidikan Uniga 8, No. 1 (2017): 1-26.

${ }^{11}$ Huriah Rachmah, “Nilai-Nilai Dalam Pendidikan Karakter Bangsa Yang Berdasarkan Pancasila Dan Uud 1945,” E-Journal Widya Non-Eksakta 1, No. 1 (2016): 7-14.

12 Zubaedi, Zubaedi, "Desain Pendidikan Karakter" (Jakarta : Kencana Prenada Media Group,2012), Cet.2. $12 ., 2012$.

${ }^{13}$ Hidayat, "Peran Dan Tantangan Pendidikan Agama Islam Di Era Global."

${ }^{14}$ Zubaedi, Zubaedi, “Desain Pendidikan Karakter" (Jakarta : Kencana Prenada Media Group,2012), Cet.2. 12.

${ }^{15}$ Ramayulis, Ramayulis, Ilmu Pendidikan Islam (Jakarta : Kalam Mulia Group,2012), Cet.9, 510., 2012.

${ }^{16}$ Ali Abdul Halim Mahmud, Ali Abdul Halim Mahmud, Akhlak Mulia (Jakarta : Gema Insani Pres, 2004), Cet.1. 32. , 2004.
} 
pertimbangan terlebih dahulu. Dengan demikian khuluq mencakup kondisi lahir dan batin manusia, baik dalam implementasi secara seksama atau tidak keseluruhan masuk dalam kategori karakter. ${ }^{17}$ Berdasarkan uraian yang ada, maka khuluq memiliki makna ekuivalen dengan karakter.

\section{METODE}

Kajian terhadap Pendidak tasawuf membangun moral menggunakan pendekatan deskreptif analisis, yakni mengkaji teori-teori berdasarkan literatur yang menjadi data utamanya, mengutif pendapat tokoh dan ulama sebagai dasar berpijak, dan menganalisas data secara komrehensif menyangkut bagian penting dan utama pada pendidikan tasawuf untuk membina moral, akhlak dan peribadi insan manusia menjadi paripurnah ${ }^{18}$.Artikel ini sepenuhnya sebagai kajian pustaka (library reseach). Berawal dari pengumpulan data tentang materi kajian tasawuf, keutamaan dimensi spiritual, dan ugensinya sebagai basis pendidikan akhlak baik sebagai individu, masyarakat bahkan pendidikan moral bangsa yang pada intinya adalah dimensi tasawuf suatu hal penting sebagai pembentukan dimensi spiritualitas seseorang ${ }^{19}$, literatus yang membahas masalah ini sudah sangat memadai untuk menuangkan kajian dan terori baru terkait tema kajian kali ini. Dan unutk lebih mendalam, tuliaan memakai pendekatan filsafat

\section{HASIL DAN PEMBAHASAN}

\section{Pendidikan Moral Dimensi Sufi}

Awal mula kejadian munculnya agama, mengandung tujuan untuk menjadi media petunjuk untuk pada seluruh umat manusia menjadi baik, bersih secara luar dan dalam, dalam arti kata, seseorang yang menjalankan dan mempedomani sebuah agama, baginya tidak secara bebas dapat melakukan segala tindakan tanpa batas, agama sudah memuat garis-garis mendasar untuk setiap yang mengimaninya, anjuran dan larangan sudah demikian rinci, namun faktanya memang banyak manusia sebagai ummat beragama masih melenceng dari nilai-nilai agama yang dianutnya. Mengapa hal itu bisa terjadi, oleh karena menjalankan agama tidak hanya bisa dilakukan sebatas membaca dan mendengarkan, yang lebih utama adalah perlu penghayatan secara mendalam hingga menyentuh aspek terdalam nilai ajaran agama itu, unsur-unsur ajaran agama mengandung ajaran lahriah sebagai syariatnya, juga mengandung nilai terdalam sebagai aspek batiniahnya (esoterik). Dengan kekuatan spiritualdalam deminsi tasawuf itulah menjadi seuatu /motor penggerak untuk menghidupkan semangat pribadi seseorang dalam rangka mencapai akhlak yang mulia, ${ }^{20}$

Penyempurnaan akhlak, kajian tasawuf menekankan pada pensucian jiwa (tazkiyah alnafs) sebagai bentuk penyucian jiwa atau ruhani seseorang. Langkah-langkah penyucian jiwa melalui tahapan pengendalian dari hal-hal tertentu sabagai manifestasi latihannya melalui riyadhah an-nafs, pencapaian akhir yang disebut sebagai tingkatan tertinggi (maqamat) spiritual sebagai dimensi zuhud. Hingga sampai pada penyaksian, sikap wujd (perjumpaan), dan fana' (peniadaan diri). ${ }^{\mathbf{2 1}}$ Dengan hati yang jernih, pandangan sufistik seseorang dipercaya akan dapat mengikhlaskan amal peribadatannya dan memelihara perilaku karena mampu merasakan kedekatan dengan Allah SWT., yang senantiasa mengawasi setiap langkah perbuatannya. Tasawuf merujuk pada dua hal pokok yaitu; penyucian jiwa (tazkyy al-Nafs) dan pendekatan diri (muraqabah) kepada Allah SWT. ${ }^{22}$

Hal yang paling urgen dalam membangun dan membuat identitas muslim masa kini adalah sistem pendidikan Islam tradisional, seperti yang diteladani oleh kaum sufi. Di

\footnotetext{
${ }^{17}$ Idrus Al-Kaf, “Dimensi Tasawuf Pendidikan Islam Dan Pencegahan Kekerasan Terhadap Anak Dalam Keluarga," Jurnal Ilmu Agama: Mengkaji Doktrin, Pemikiran, Dan Fenomena Agama 19, No. 2 (2018): 248-58.

${ }^{18}$ Tjutju Soendari, "Metode Penelitian Deskriptif," Bandung, Upi. Stuss, Magdalena \& Herdan, Agnieszka 17 (2012).

${ }^{19}$ Muhammad Anas Maarif, “Tasawuf Falsafi Dan Implikasinya Dalam Pendidikan Islam,” Vicratina: Jurnal Pendidikan Islam 3, No. 1 (2018).

${ }^{20}$ Jauhar Fuad, “Pendidikan Karakter Dalam Pesantren Tasawuf," Tribakti: Jurnal Pemikiran Keislaman 23, No. 1 (2012).

${ }^{21}$ Maarif, "Tasawuf Falsafi Dan Implikasinya Dalam Pendidikan Islam."

${ }^{22}$ Mustofa Aris, "Muraqabah Sumber Kebahagiaan Hidup Di Tengah Keringnya Spiritulitas Masyarakat Modern; Analisis Konsep Muraqabah Ibn Qayyim Al-Jawziyah Dalam Kitab Madarij Al-Salikin" (Uin Sunan Ampel Surabaya, 2019).
} 
Indonesia telah tercatat betapa besar pengaruh tasawuf ke dalam dunia pendidikan sebelum masa kemerdekaan. Pengaruh tasawuf sudah sejak lama memasuki lembaga-lembaga pendidikan seperti Pesantren Salafiyah, Jami'at Khair, Madrasah al-Khaerat, Nahdatul Ulama dan Pesantren. ${ }^{23}$

Kini saatnya lembaga pendidikan Islam mensosialisasikan dan menginternalisasikan dimensi batiniah Islam kepada peserta didik (murid tholib) sebagai alternativ. Islam perlu disosialisasikan pada mereka, setidak-tidaknya ada tiga tujuan utama. Pertama, turut serta berbagai peran dalam menyelamatkan kemanusiaan dari kondisi kebingungan sebagai akibat dari hilangnya niali-nilai spiritual. Kedua, memperkenalkan literatur atau pemahaman tentang aspek esoteris Islam, terhadap masyarakat Barat modern. Ketiga, untuk memberikan penegasan kembali bahwa sesungguhnya aspek esoteris Islam, yakni tasawuf adalah jantung ajaran Islam, sehingga bila wilayah ini kering dan tidak lagi berdenyut, maka keringlah aspekaspek lain dari ajaran Islam. ${ }^{24}$

Ada tiga tatanan Islam yang dapat mempengaruhi umat manusia. Pertama, ada kemungkinan mempraktekkan ajaran spiritual Islam secara aktif. Pada tahap ini orang harus membatasi kesenangan terhadap dunia materi dan kemudian mengarahkan hidupnya untuk bermeditasi, berdo'a, mensucikan batin, mengkaji hati nurani, dan hidupnya untuk melakukan praktek-praktek ibadah lain (mujahadah dan riyadhah). Mujahadah adalah memerangi atau mencegah kecenderungan hawa nafsu dari masalah-masalah duniawi. Mujahadah yang lazim berlaku di kalangan orang 'awam' adalah berupa perbuatan-perbuatan lahiriyah yang sesuai dengan ketentuan syari'at. Sementara di kalangan khawazh, mjahadah dimaknai sebagai usaha keras mensucikan batin dari segala akhlak tercelah ${ }^{\mathbf{2 5}}$. Mujahadah yang berat dan lama yang dipusatkan untuk mematikan segala keinginannya selain kepada Allah, dan menghancurkan segala kejelekannya dan menjalankan bermacam riyadhah yang diatur dan ditentukan oleh para sufi sendiri. ${ }^{26}$

Kedua, tasawuf mungkin sekali mempengaruhi Barat dengan cara menyajikan Islam dalam bentuk yang lebih menarik, sehingga orang dapat menemukan praktek-prkatek tasawuf yang benar. Maka, umat Islam harus mampu menyajikan dan mendakwakan Islam kepada umat manusia dengan lebih menarik, yakni keseimbangan atara aktivitas duniawi dengan ukhrawi.

Cara seperti ini telah dipraktekkan secara sukses dalam penyiaran Islam di India, Indonesia, dan Afrika Barat. Ketiga, dengan mempraktekkan ajaran tasawuf sebagai alat bantu untuk mengingatkan membangun jiwa-jiwa yang tidur. Karena tasawuf merupakan tradisi yang hidup dan kaya dengan doktrin-doktrin metafisis, kosmologis, dan psikologis serta psikoterapi religious, maka berarti tasawuf atau sufisme akan dapat menghidupkan kembali berbagai aspek kehidupan rohani umat manusia yang selama ini tercampakkan dan terlupakan.

\section{Urgensi Pendidikan Tasawuf}

Sejak awal budaya manusia, pendidikan pada hakikatnya merupakan proses sosialisasi dan enkulturasi yang menyebabkan nilai-nilai dan pengetahuan-pengetahuan yang terakumulasi di masyarakat. ${ }^{27}$ Dengan berkembangnya masyarakat, maka berkembang pula proses sosialisasi dan enkulturasinya dalam bentuknya yang diserap secara optimal. Dewasa ini pendidikan terlihat lebih mengupayakan peningkatan potensi intelegensi manusia. IQ telah menjadi sebuah "patok absolut" dalam melihat tingkat progresivitas kedirian manusia. ${ }^{28}$ Manusia dituntut mengasah

\footnotetext{
${ }^{23}$ Siti Maryam Munjiat, “Peran Tasawuf Dalam Pendidikan Karakter," Al-Tarbawi Al-Haditsah: Jurnal Pendidikan Islam 3, No. 2 (2018).

${ }^{24}$ Marhani M Ag, "Aktualisasi Tasawuf Al-Ghazali Dalam Mengantisipasi Krisis Spiritual," Fikratuna: Jurnal Penelitian Sosial Keagamaan 9, No. 1 (2018).

${ }^{25}$ Munjiat, "Peran Tasawuf Dalam Pendidikan Karakter."

${ }^{26}$ Munjiat.

${ }^{27}$ Asep Kurniawan, “Peran Tasawuf Dalam Pembinaan Akhlak Di Dunia Pendidikan Di Tengah Krisis Spritualitas Masyarakat Modern," Jurnal Tasawuf 2, No. Juni (2016): 80-98.

${ }^{28}$ Munjiat, "Peran Tasawuf Dalam Pendidikan Karakter.”
} 
ketajaman intelektualnya demi kemampuan mengoperasikan mekanisme alam yang menurut Juragan Habermas, menghujamnya hegemoni rasio instrumentalis. Produk dari instrumentalisasi intelek ini adalah terbangunnya manusia-manusia mekanis yang kering dari nuansa kebasahan ruang diri, atau dalam istilah Herbart Marcuse, one dimensional men.

Gambaran di atas, mengisyaratkan pendidikan pun perlu diarahkan untuk melakukan perombakan substansial menuju penyadaran hakiki dengan bertumpu pada pemaknaan hidup secara lebih humanis. Perubahan ini sepatutnya dibidikkan pada wilayah esoterik yang merupakan kesadaran hakiki yang berwatak multidimensional.Kesadaran esotieris senantiasa meneguhkan nilai-nilai keilahian yang menjadi sumber segala bentuk kesadaran. Padahal, kesadaran akan hadirnya kekuatan ilaahiah bisa menghadirkan kesadaran praksis yang amat signifikan bagi pengembangan kepribadian baik privat maupun sosial.

Pada bagian lebih penting setelah toleransi beragama, ada pemikiran yang berlandaskan pendalaman wisdom tentang pemikiran yang substansial, universal, ${ }^{29}$ dan integral melalui jalur yang emansipatoris, moralis, dan spiritual. Sebuah pengayaan proses pendidikan yang berlandaskan nilai-nilai tasawuf dengan tujuan praksis sosial. Tasawuf bukan penyikapan pasif atau apatis terhadap terhadap kenyataan sosial, namun tasawuf berperan besar dalam mewujudkan sebuah revolusi spiritual di masyarakat.Bukanlah aspek moral-spiritual ini sebagai ethical basic bagi formulasi dunia pendidikan. Kau sufi adalah elite di masyarakat dan sering memimpin gerakan penyadaran akan adanya penindasan dan penyimpangan sosial. ${ }^{30}$ Tasawuf merupakan metodologi pembimbingan manusia menuju keharmonisan dan keseimbangan total. Interaksi kaum sufi dalam semua kondisi adalah harmoni dan kesatuan dengan totalitas alam, sehingga perilakunya tampak sebagai manifestasi cinta dan kepuasan dalam segala hal.

Bertasawuf berarti pendidikan bagi kecerdasan emosi dan spiritual (ESQ) yang sebenarnya adalah belajar untuk tetap mengikuti tuntutan agama, ${ }^{31}$ saat berhadapan dengan musibah, keberuntungan, perlawanan orang lain, tantangan hidup, kekayaan, kemiskinan, pengendalian diri, dan pengembangan potensi dari diri. Bukankah lahiriyah sufi-sufi besar seperi Rabi'ah al-Adawiyah, al-Ghazali, Sari al-Saqoth atau Asad al-Muhasabi telah memberi teladan, pendidikan yang baik, yakni berproses menuju perbaikan dan pengembangan diri dan pribadi. ${ }^{32}$

Menjadi kesadaran, bahwa pendidikan yang dikembangkan masih terlalu menekankan akademik, kecerdasan otak, dan jarang sekali pendidikan tentang kecerdasan emosi dan spiritual yang mengajarkan integritas, kejujuran, komitmen, visi, kreativitas, ketahanan mental, keadilan, kebijaksanaan, prinsip kepercayaan, penguasaan diri atau sinergi. ${ }^{33}$ Akibatnya, berkecambahnya krisis dan degradasi.Dalam ranah moral, sumber daya manusia dan penyempitan cakrawala berpikir yang berakibat munculnya militansi sempit atau penolakan terhadap pluralitas.Dalam tasawuf, antara IQ (dzaka al-Dzihn), EQ (tashfiat al-Qolb) dan SQ (tazkiyah a-nafs) dikembangkan secara harmoni, sehingga menghasilkan daya guna yang luar biasa, baik secara horizontal maupun vertikal.

\section{KESIMPULAN}

\footnotetext{
${ }^{29}$ Khoirul Azhar And Izzah Sa'idah, "Studi Analisis Upaya Guru Akidah Akhlak Dalam Mengembangkan Potensi Nilai Moral Peserta Didik Di Mi Kabupaten Demak," Al-Ta'dib: Jurnal Kajian Ilmu Kependidikan 10, No. 2 (2017).

${ }^{30}$ Muhammad Syafiuddin, “Pendidikan Karakter Dalam Perspektif Filsafat Pancasila (Studi Pemikiran Bung Karno)” (Uin Raden Intan Lampung, 2018).

${ }^{31}$ Novi Ilham Madhuri, “Pengaruh Kecerdasan Emosional, Kecerdasan Spiritual Dan Perilaku Belajar Terhadap Indeks Prestasi Komulatif Mahasiswa," Jpeka: Jurnal Pendidikan Ekonomi, Manajemen Dan Keuangan 1, No. 1 (2017): 31-43.

${ }^{32}$ Galuh Woro Iklima, "Peran Guru Agama Islam Dalam Mengembangkan Kecerdasan Emosional Dan Spiritual Siswa Di Smk Negeri 1 Jambu Tahun Pelajaran 2016/2017" (Iain Salatiga, 2017).

${ }^{33}$ Yuni Eka Khanifatuzzuhro, "Kecerdasan Emosional Dan Spiritual (Esq) Peserta Didik Di Smk N 1 Negerikaton Kecamatan Negerikaton Kabupaten Pesawaran" (Uin Raden Intan Lampung, 2019).
} 
Pendidikan ilmu tasawuf yang dipraktekkan seseorang, ia dikenal dengan sebutan Sufistik, ${ }^{34}$ yakni ia menjalankan praktis sufi dalam kehidupan empirik sehingga kepadatan sosial, ekonomi,politik, dan keberagamaan mendapatkan kecerahan dari sisi kemanusiaan dan dihayati logika sejarah kritis dan dinamis. ${ }^{35}$ Bukan lari dari kecenderungan ekonomi dan politik yang culas dan korup, tetapi sebuah hasil kerja keras menahan diri mengatasi perangkap finalitas serupa ketika ditujukan hanya untuk meraih pahala sebesar mungkin tanpa keterkaitan fungsional pemecahan problem kehidupan riil.Prestasi sosial, ekonomi, politik dan kesalehan religious lebih bermakna saat seseorang memasuki wilayah tanpa batas penuh kenikmatan hidup dan melampaui dimensi bendawi.Sufistisasi produktif penting dalam keberagamaan non-produktif yang bersifat fatalis yang lebih menekankan pencarian kekayaan moral-spiritual menolak kekayaan dan kuasa bendawi. Pemahaman ajaran zuhud seperti itulah salah satu penyebab ketertinggalan masyarakat muslim yang miskin dan terbelakang. Metode ma'rifat yang futuristik itu menciptakan manusia-manusia yang piawai melihat hukum sejarah, dan berbagai kemungkinan kejadian di masa depan, sehingga mampu memberikan orang yang menggeluti dunia pendidikan menjadi lebih terarah dan optimal. ${ }^{36}$

Model pendidikan tasawuf menekankan peran ihsan dalam perbuatan yang kemudian memunculkan akhlak yang baik. Ajaran tasawuf yang memasuki ruang esoterik menyebabkan timbulnya akhlak sebagai alat control psikis dan sosial bagi insan akademik dan para pendidik. Tanpa model Pendidikan duniaakan dihuni oleh materialisme tidak memahami makna penting dari nilai kehidupan itu sendiri. Dalam kaitan ini, maka nilai-nilai spiritual dan akhlak mulai hendaknya dikembangkan dalam pendidikan terlebih dahulu dalam suasana kekeringan spiritualitas dewasa ini.

Pada bagian ini, tasawuf berperan dengan olah ruhaniyah menjadi penawar yang bisa menstabilkan kondisi kritis jiwa pendidikan moder yang individualistik-materialistik sekularistik.Ajaran kedamaian, cinta serta kasih sayang dalam dunia tasawuf adalah segmen yang cukup menarik untuk disingkap, sekaligus sebagai upaya membantu tatanan kehidupan yang harmonis.

\section{REFERENSI}

Adawiyah, Robiah. "Implikasi Hermeneutika Al-Quran Fazlurrahman Dan Hasan Hanafi Terhadap Penetapan Hukum Islam." Syariati: Jurnal Studi Al-Qur'an Dan Hukum 2, No. 01 (2016): 17-28.

Ag, Marhani M. "Aktualisasi Tasawuf Al-Ghazali Dalam Mengantisipasi Krisis Spiritual." Fikratuna: Jurnal Penelitian Sosial Keagamaan 9, No. 1 (2018).

Ainissyifa, Hilda. "Pendidikan Karakter Dalam Perspektif Pendidikan Islam." Jurnal Pendidikan Uniga 8, No. 1 (2017): 1-26.

Al-Kaf, Idrus. "Dimensi Tasawuf Pendidikan Islam Dan Pencegahan Kekerasan Terhadap Anak Dalam Keluarga." Jurnal Ilmu Agama: Mengkaji Doktrin, Pemikiran, Dan Fenomena Agama 19, No. 2 (2018): 248-58.

Ali Abdul Halim Mahmud. Ali Abdul Halim Mahmud, Akhlak Mulia (Jakarta : Gema Insani Pres, 2004$),$ Cet.1. 32., 2004.

Amran, Ali. "Peranan Agama Dalam Perubahan Sosial Masyarakat." Hikmah: Jurnal Ilmu Dakwah Dan Komunikasi Islam 2, No. 1 (2015): 23-39.

Aris, Mustofa. "Muraqabah Sumber Kebahagiaan Hidup Di Tengah Keringnya Spiritulitas Masyarakat Modern; Analisis Konsep Muraqabah Ibn Qayyim Al-Jawziyah Dalam Kitab Madarij Al-Salikin." Uin Sunan Ampel Surabaya, 2019.

Azhar, Khoirul, And Izzah Sa'idah. "Studi Analisis Upaya Guru Akidah Akhlak Dalam Mengembangkan Potensi Nilai Moral Peserta Didik Di Mi Kabupaten Demak." Al-Ta'dib: Jurnal Kajian Ilmu Kependidikan 10, No. 2 (2017).

Basyari, Iin Wariin. "Menanamkan Identitas Kebangsaan Melalui Pendidikan Berbasis Nilai-Nilai Budaya

\footnotetext{
${ }^{34}$ Syamsun Niam, “Institusi Pendidikan Dalam Tasawuf," Jurnal Kanz Philishophia 3, No. 2 (2013).

${ }^{35}$ Muhamad Rifa'i Subhi, “Pendekatan Sufistik Dalam Pendidikan Islam (Telaah Pemikiran Hamka),” Edukasia Islamika, 2017, 6288.

${ }^{36}$ Muhamad Basyrul Muvid, Pendidikan Tasawuf: Sebuah Kerangka Proses Pembelajaran Sufistik Ideal Di Era Milenial (Pustaka Idea, 2019).
} 
Lokal." Edunomic Jurnal Pendidikan Ekonomi 1, No. 2 (2013).

Departemen Agama, R I. “Mushaf Al-Qur'an Dan Terjemah." Jakarta: Pustaka Al-Kautsar, 2009.

Fazlur Rahman. Fazlur Rahman, Islam, (Bandung: Pustaka, 1404 H-1984 M), H. 36., N.D.

Fuad, Jauhar. "Pendidikan Karakter Dalam Pesantren Tasawuf." Tribakti: Jurnal Pemikiran Keislaman 23, No. 1 (2012).

Hidayat, Nur. "Peran Dan Tantangan Pendidikan Agama Islam Di Era Global." Jurnal Pendidikan Agama Islam 12, No. 1 (2015): 61-74.

Iklima, Galuh Woro. "Peran Guru Agama Islam Dalam Mengembangkan Kecerdasan Emosional Dan Spiritual Siswa Di Smk Negeri 1 Jambu Tahun Pelajaran 2016/2017." Iain Salatiga, 2017.

Khanifatuzzuhro, Yuni Eka. "Kecerdasan Emosional Dan Spiritual (Esq) Peserta Didik Di Smk N 1 Negerikaton Kecamatan Negerikaton Kabupaten Pesawaran." Uin Raden Intan Lampung, 2019.

Kurniawan, Asep. "Peran Tasawuf Dalam Pembinaan Akhlak Di Dunia Pendidikan Di Tengah Krisis Spritualitas Masyarakat Modern." Jurnal Tasawuf 2, No. Juni (2016): 80-98.

Maarif, Muhammad Anas. "Tasawuf Falsafi Dan Implikasinya Dalam Pendidikan Islam." Vicratina: Jurnal Pendidikan Islam 3, No. 1 (2018).

Madhuri, Novi Ilham. "Pengaruh Kecerdasan Emosional, Kecerdasan Spiritual Dan Perilaku Belajar Terhadap Indeks Prestasi Komulatif Mahasiswa." Jpeka: Jurnal Pendidikan Ekonomi, Manajemen Dan Keuangan 1, No. 1 (2017): 31-43.

Munjiat, Siti Maryam. "Peran Tasawuf Dalam Pendidikan Karakter." Al-Tarbawi Al-Haditsah: Jurnal Pendidikan Islam 3, No. 2 (2018).

Muslim, Asrul. "Interaksi Sosial Dalam Masyarakat Multietnis." Jurnal Diskursus Islam 1, No. 3 (2013): 48394.

Muvid, Muhamad Basyrul. Pendidikan Tasawuf: Sebuah Kerangka Proses Pembelajaran Sufistik Ideal Di Era Milenial. Pustaka Idea, 2019.

Niam, Syamsun. "Institusi Pendidikan Dalam Tasawuf." Jurnal Kanz Philishophia 3, No. 2 (2013).

Rachmah, Huriah. "Nilai-Nilai Dalam Pendidikan Karakter Bangsa Yang Berdasarkan Pancasila Dan Uud 1945." E-Journal Widya Non-Eksakta 1, No. 1 (2016): 7-14.

Ramayulis. Ramayulis, Ilmu Pendidikan Islam (Jakarta : Kalam Mulia Group,2012), Cet.9, 510., 2012.

Soendari, Tjutju. "Metode Penelitian Deskriptif." Bandung, Upi. Stuss, Magdalena \& Herdan, Agnieszka 17 (2012).

St Aisyah, B M. "Konflik Sosial Dalam Hubungan Antar Umat Beragama." Jurnal Dakwah Tabligh 15, No. 2 (2014): 189-208.

Subhi, Muhamad Rifa'i. "Pendekatan Sufistik Dalam Pendidikan Islam (Telaah Pemikiran Hamka)." Edukasia Islamika, 2017, 62-88.

Syafiuddin, Muhammad. "Pendidikan Karakter Dalam Perspektif Filsafat Pancasila (Studi Pemikiran Bung Karno)." Uin Raden Intan Lampung, 2018.

Zubaedi. Zubaedi, "Desain Pendidikan Karakter" (Jakarta : Kencana Prenada Media Group,2012), Cet.2. 12., 2012. 